\title{
A study of general academic English writing and critical thinking
}

\author{
Mao Fanjiao \\ Changsha Medical University Huanan Changsha 410000
}

\begin{abstract}
From Dewey (JohnDewey) critical thinking is put forward, scholars at home and abroad to carry out the process of students' English writing ability of critical thinking ability. Almost from the beginning of the 19th century, Europe and the United States and other countries to critical thinking ability in higher education target. In recent years, the domestic educational circles also began to focus on critical thinking ability. General academic English compared with special use English, to take the test in a different way, general academic English lay particular stress on practicality, mass communication can satisfy the mass people and work. Is now under the condition of domestic general academic English writing ability training, focus on English vocabulary, beautiful language section of references, the mechanical model stage, how to cultivate critical thinking in the process of general academic English writing, is the key breakthrough of colleges and universities nowadays research subject, this to promote the development of language learners, plays an important role.

Key word: General academic English writing Critical thinking ability
\end{abstract}

\section{Introduction}

With the development of society, the higher education in our country is in line with international standards, criticized the new thinking by domestic academic circles and educational circles of scholars, critical thinking as a way of thinking is the people questioned the idea or behavior, the use of standards or norms issued by the appropriate do fully justified judgment. Visible critical thinking instruction 
for general English academic writing, can cultivate students' creative thinking ability and research ability, for the general academic writing ability has a significant effect.

At present, many domestic colleges and universities, students' English writing quality is reduced, through the relevant data that traditional teaching method is the main reason why the general academic English writing level is reduced, the author through visits in universities, found that teachers in Colleges and universities for academic English writing course in cultivating students' critical thinking, students of English the writing level can be improved, the teaching goal can be successfully completed.

\section{The connotation and structure of critical thinking}

The connotation of critical thinkingCritical thinking mainly refers to can be acquired through learning and training, the modern concept of critical thinking is the first Dewey, Dewey think that critical thinking is the basis for any individual beliefs or assumptions and the basis and further deduce the conclusion of positive, lasting and careful thinking. The domestic scholars on the definition of critical thinking each are not identical, but in general, critical thinking comes from reflection, combined with the actual situation and Reflection on the experience, the use of existing knowledge, skills and objective standard of things or phenomena is not really pseudo making a judgment.

Our country scholar Luo Qingxu thinks that critical thinking is not only a kind of thinking ability, more is the quality of individuals tend to exhibit. Critical thinking tends to be more flexible and individual self guidance, restriction, supervision and correction of thinking. From the current situation of education in our country, the lack of critical thinking, the traditional education is mainly dominated by the lack of to cultivate students' innovative spirit, for students' self adjustment and reflection ability lack.

the structure of critical thinking, there are differences between the scholars at home and abroad in the definition of critical thinking. According to the author's own summary and analysis, the author thinks that the structure of the critical thinking has the following four ways: FRISCO single dimensional structure of Ennis, which is in accordance with the concerns, logical analysis, conclusion, context, concept analysis and review process. The single dimensional structure is the focus on skills of critical thinking, focuses on the things to consider to critical thinking, with focus on critical thinking. two dimensional structure of Facione, mainly refers to the critical thinking is divided into two aspects of cognitive ability and cognitive ability to examine the tendency of scholars, interpretation, analysis, evaluation, reasoning, interpretation and 6 aspects of self adjustment ability; tendency to examine the scholars to seek truth, open thinking, analysis system 7, confident, good ask and mature. In simple terms, their emotional double dimensional structure more scholars attention, subjective feelings, the relative lack of objective factors. Three element structure model of Paul and Elder, the model is mainly according to 10 criteria, 8 intelligence characteristic, 8 
thinking elements. To describe the critical thinking structure is relatively objective and scientific, this model is relatively other models, respected by scholars in foreign language field. hierarchical model of Wen Qiufang, the thinking model in three yuan continued to refine the structure model of Paul and Elder, the ability is divided into two levels, the first level is the ability of second yuan, the level of thinking ability. Foreign language has many scholars to Wen Qiufang's hierarchical model of recognition, and to be used in the general academic English writing.

\section{The general academic English writing problems}

Critical thinking in general, refers to the things, phenomena or a point of view, independent thinking and observation, put forward their own views, not blindly agree with others views. When the point of view should be supported by the evidence and evidence of the basis, sorting and analysis, the use of logical language statements, pay attention to the problem of students' ability to find problems, language ability and logical thinking ability. However, the teaching situation of domestic institutions of higher learning, the traditional mode of teaching students lack critical thinking. In the traditional curriculum, the emphasis is on students' ability to use language, which is the ability of students to imitate. The lack of students in this mode of education is the ability to think and think independently.

The general academic English writing course focuses on the practicality of the public, the application of critical thinking in the domestic higher education system, there are still vacancies, few college teachers will be the classroom to the students, most of the teachers to explain the combination of class After practice, the general academic English writing has a fixed template, the students in the classroom is a passive receiver. Teachers tend to ignore the subjective feelings of students, students are the bearer of the model of teacher lectures, most teachers use the blackboard mode, the examination also used paper examination, the right to the same thinking mode, the students are mainly listening and practice, The critical thinking of students in general academic English writing is repression.

In recent years, the general application of academic English emphasis on practical operability, the country's education system reform, the introduction of foreign advanced teaching system, the level of students' English writing began to attach importance to the process of writing students self-emotional investment. Relevant institutions of higher learning to redesign the structure and content of English to English practice-oriented, mainly to develop students' English application ability as the focus, attention to students in the learning process of critical thinking. But under the current educational mechanism, there are still some deficiencies in the teaching objectives, curriculum design, teaching content and classroom order in the general academic English writing course, and the emphasis on the critical thinking is not enough. There are two main aspects of this situation; one aspect of non-English majors in English comprehensive ability compared to professional students thinking ability is low, the foundation is not 
enough, if the English teaching objectives to the critical thinking ability, zero The basic or poor foundation of poor students learning; the other hand, the traditional teaching model is still classroom-led, few teachers can really put the classroom students, teachers do not establish critical thinking classroom teaching concepts, curriculum The goal of education is always the ultimate goal of classroom teaching, and many teachers' own knowledge and ability of critical thinking teaching needs to be improved, and the cultivation of critical thinking ability and teaching practice can not be combined organically.

\section{The training of critical thinking ability in academic English teaching}

General academic English writing is an important way of modern international communication. With the pace of globalization, the application of many documents has been extended to all aspects of public life. The traditional students who meet the basic English writing pattern are no longer needed by enterprises. Of the talent, and now the employment situation, many companies need is an international perspective, through the international rules, to participate in international affairs and international competition of international talent, so the institutions of higher learning in training students' English writing ability, Should be more emphasis on improving students 'ability to use language integrated, the quality of humanities, cross-cultural communication skills, based on solid English, the importance of training students' critical thinking ability of academic literacy. Combined with multimedia resources, the concept of teachers, teaching methods of innovation, curriculum content should also be with the international form of innovation.

The traditional teaching idea of our country is deep-rooted, the traditional mode of thinking should accept the innovation of reality. Therefore, the lecturers of colleges and universities should set up their own critical thinking teaching ideas. In the process of class teaching, students should cultivate their own critical Thinking ability, teachers in addition to focus on grammar, statements and other basic knowledge to explain, the other classroom time should be handed over to the students to encourage students to the existing general academic English writing courses to raise their own opinions, encourage students to innovate thinking and encourage students to innovate In combination with practice, teachers should also establish the concept of critical thinking education, change the traditional teaching methods of classroom knowledge, and combine students' characteristics to encourage students to participate in classroom activities.

Colleges and universities are part of higher education, in the cultivation of higher talent, so that students in the classroom and extracurricular have a certain number of words accumulated, based on grammar accurate use of reading speed to achieve educational goals, set the relevant research room, Common problems common to college students, come up with solutions. To set up an incentive mechanism to encourage students in the general academic English writing 
teaching process, learn to question, and to discover the problems in-depth exploration, come up with a reasonable logical and reasonable program,

In the course of teaching, teachers of general academic English writing course should take the textbook as the main battlefield and widen students extracurricular knowledge, encourage students to acquire knowledge through the process of discovery, criticism, research, reflection and comment, teachers are students, Supervise students to achieve teaching objectives, set reasonable judgments or evaluation activities, so that students in the course of practice to improve the general level of academic English writing to encourage students to participate in critical discussions, so as to develop students critical thinking skills.

General academic English writing and professional academic English writing, there are professional differences, require students to master the basic writing method, do not need more specialized terms of learning, in the teaching material set, should cover the interdisciplinary general knowledge And professional knowledge of popular science, the combination of critical thinking teaching and regular English classroom teaching, focusing on training students to obtain the content of subject content, analysis, integration and judgments ability to cultivate critical reading and thinking skills.

Course setting, do not need too much academic professional curriculum, should focus on the practical ability to set, of course, the necessary academic English teaching students to reinforce the language skills and improve the professional English level, in the curriculum, should take into account General academic writing in the mass, in the development of academic English ability, academic literacy, let students tend to discuss. Students will be able to think through their own problems, question the existence of the problem, and then work together to avoid the students focus on the theory of English writing remarks.

As the leading student of English writing, teachers play an important role in guiding students 'learning. The training of students' critical thinking ability in general academic English writing focuses on the way of thinking of students. Teachers should play the role of guide in the whole teaching process. In the course of teaching practice, the students are encouraged to start from the discourse theme or background, pay attention to the meaning of the content, the purpose of writing, the use of mood and other points of view, the teacher through logical explanation and analysis for students to question the things one And finally realize the critical thinking methods and strategies around students 'understanding, analysis and evaluation of their argumentation to train students to raise and solve problems, and to promote the cultivation of students' critical thinking ability.

\section{Acknowledgment}

Research project: Hunan Provincial Department of education research project, code: 16C0188 General academic English writing and Critical thinking 


\section{References}

[1] Li Dan. University of Academic Writing in the critical thinking of the training [J].Journal of Shangqiu Vocational and Technical College, 2014,01: 77-79.

[2] $\mathrm{Su}$ Wen-cai. Based on the academic English teaching model of critical thinking of students [J]. Education and Teaching Forum, 2014,46: 250-252.

[3] Yang Feng. "Integration of College English" Compendium of the concept of [J] Contemporary Foreign Language Research, 2016,05: 60-63 +94.

[4] Xu Dandan. General academic English writing curriculum environment under the thinking ability of students [D]. East China University of Science and Technology, 2015.

[5] LIANG Xiao-hui, SUN Kai-meng.Creation of innovation ability and preparation of "Academic English Reading and Writing Course" [A]. Contemporary Foreign Language Education 2016 (Volume 1) [C]., 2016: 7.

[6] HE Ling-mei.Cultural understanding of the English professional education [D]. East China Normal University, 2014. 